\section{噴火湾西岸北部海岸段丘構成物の堆積環境}

瀨川秀良

北海道噴火湾西岸北部の長万部町 ·国縫町方 面には 2 段の海岸段丘が存在し, 筆者は上位の 段丘を長万部段丘，下位の万丘を長万部神社段 丘と名づけた。長万部段丘は針谷ら（1959）の 下位段丘に相当する。

上位段丘の堆積物は国縫歌南方約 $3 \mathrm{~km}$ の段 丘崖において网のようになっている。段丘堆積 層下部に和いて基盤岩が見出されず，スコリア と砂碟層が互層をなすことは，この地域が比較 的著しい火山作用の影響をう壮つつ，一進一退 しながらる全体的にはわずかづつ浅海地带で沈

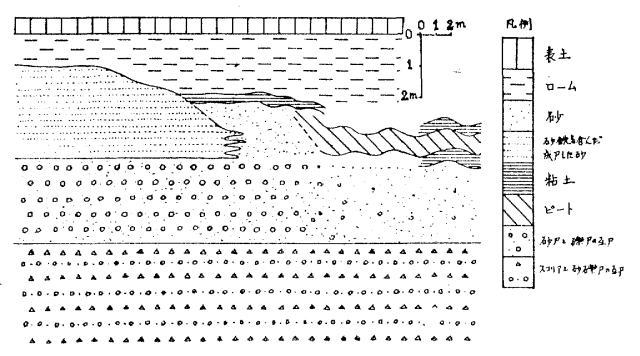

下をつづけたことを示している。ついで砂層と 硶層の互層の時代には火山活動が終り, やや海 退に転じたと思われる。これらの上の堆積物の 横の変化をみると，海岸汇近い方面では砂鉄を 含しだ成層した砂層が堆積しこれに連続して 泥炭や粘土層が砂層と同時異相をなしている。 また，この成層した砂鉄を含んだ砂層の上面は 東から西低くなり，侵蝕された面で，その上 にローム層をのせるが，当時の地形面を示して いる。

これらの事実は現在の海岸附近の地形や堆積 物で見るように，砂鉄を含む砂丘とその背後の 後背湿地や泥炭質堆積物との関係でありまた 砂鉄を含んだ成層した砂層の巾も約 $15 \mathrm{~m}$ 位で 現在の砂丘の巾と大差なく，上位段丘形成末期

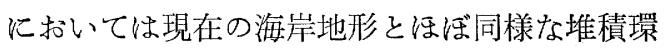
境であったと思われる。(1965.12.6 受理)

針谷省・堤季造（1959）：太平洋沿岸地带砂鉄鉱床 北海道の未利用鉄資源調查報告第 7 輯 $57-60$

\title{
Sedimentary Environment of the Upper Terrace at the Northern Part of the Western Coast of Hunka Bay, Hokkaido
}

\author{
Shūryō SEGAWA
}

\begin{abstract}
There are two marine terraces at the northern part of the western coast of Hunka Bay, Hokkaido. The upper terrace deposits have the sediments of sand dune, peat and clay, and they deposited at the same geological time. The sediments of the present coast of Hunka Bay are also sand dune, peat and clay. By the comparison of the terrace and present deposits, the writer considered that the marine terrace deposits were perhaps sedimented under the same circumstance as the present.
\end{abstract}

\section{Frontal Zones and the Shurin (Autumn Rain) around Japan Hyo-e TAMIYA and Takeshi SEKIGUTI}

The most and the least rainy decade during the Shurin period of the year was identified respectively for the period of 1958-61, and numbers of nation-wide cloudy and rainy weathers were counted for both decades. And geographical locations of the fronts were checked respectively on each $2^{\circ}$ quadrangle of lat. andlong. and the composite maps of ocurring frequencies (\%) of the fronts (Figs. 1 and 2) were constructed for both decades.

The total counts of the fronts around Japan were almost same; in average 25 counts per day for the most rainy decades and 24 for the least rainy decades. Also distribution patterns of the frontal system ware sinilar exsh othor. Only difference was the relative locations of the frontal system to the Japanese Islands. About $700 \mathrm{~km}$ 's northeastward shifting of the frontal system. from the location at the most rainy decales became that of the least rainy one. But it may not be reasonable to say that the aproush of the frontal system to Japanese coast from SE in early autumn results fine weather. 